\title{
An Analysis of COVID-19 \\ - Related Fake News from Romania. A Pilot Qualitative Study
}

\author{
Ioana PALADE, PhDc
}

Department of Communication, PR, and Advertising

Faculty of Political, Administrative and Communication Sciences

Babes-Bolyai University, Cluj-Napoca, Romania

E-mail: ioana.palade@fspac.ro

\section{Prof. Delia Cristina BALABAN, PhD}

Department of Communication, PR, and Advertising

Faculty of Political, Administrative and Communication Sciences

Babes-Bolyai University, Cluj-Napoca, Romania

E-mail: balaban@fspac.ro

\begin{abstract}
At the beginning of the novel coronavirus another phenomenon was observed: the dissemination of false information on a large scale. The World Health Organization (WHO) stated that the coronavirus pandemic is not the only threat that the world is facing, but there is also an infodemic that needs to be controlled. For example, false articles claiming that SARS$\mathrm{CoV}-2$ was man-made or that the EU is going to be eradicated are invading the health sector. This pilot study aims to analyze several COVID-19 related fake news disseminated in Romania that was identified as fake by traditional media outlets. A content analysis of $N=22$ COVID-19 related fake news was conducted using a coding scheme adapted from Keselman et.al. (2019). The articles were written in a colloquial language, and the majority of them included criticism towards the government and their measures against the pandemic. Some of the distinguished features of fake
\end{abstract}


news according to previous literature in the field were identified in the examples that we chose.

Keywords: Fake news; COVID-19; eHealth literacy; Infodemia; Misinformation.

\section{Introduction}

In January 2020, an outbreak of a novel coronavirus disease called COVID-19 was reported in Wuhan, China. The infection spread rapidly in the city and across China, and started to extend in other countries (Sun, Chen, \& Viboud, 2020). At that time, the scale of the spreading of the disease was unknown to the scientists (Shimizu, $2020,686)$. The virus that responsible for COVID-19 was called SARS-CoV-2 and proved to be extremely contagious and dangerous especially for vulnerable groups: people with health conditions and older people (Kwok et al., 2020). No universal cure for this disease is yet available, this leaving place for fake news regarding false miraculous treatments that circulate on the Internet and also not to try medicines that have not been thoroughly studied ("Fighting disinformation," 2020). To reduce the number of infections, governments from different countries around the world implemented several strategies including lockdowns towards slowing the transmission of the virus. Measuring body temperature, quarantining, and isolating the individuals that traveled abroad, and social distancing are some of the strategies adopted in many countries (Kwok et al., 2020).

The novel coronavirus (COVID-19) pandemic proved to be a great burden for global health and in particular for the countries that implemented social distancing measures with a time delay (Shimizu, 2020). The pandemic caused a great number of hospitalizations stretching the above the limits medical systems around the world that were not designed to face an unprecedented situation like this one (Kouzy et al., 2020).

The World Health Organization, trough the voice of its director stated that the coronavirus pandemic is not the only threat that the world is facing, but there is also an infodemic that needs to be controlled (Nielsen, Fletcher, Newman, Brennen, \& Howard, 2020). Fabricated information is "spreading faster than the virus" ("Disinformation: how to recognize and tackle COVID-19 myths," 2020). All across the globe, the topic of COVID-19 is prone to misinformation and disinformation, since false or misleading articles are being published on this topic. These false articles can have negative consequences not only for the people's lives in particular but for entire societies and the democratic system. Disinformation campaigns regarding coronavirus tackle topics like the source of the virus or the authorities' efforts towards controlling the pandemic, but sometimes, these disinformation 
messages are targeting the EU actions that are being taken for fighting the disease. ("EEAS special report update: short assessment of narratives and disinformation around the COVID-19 pandemic," 2020) For example, there are fake news-based articles, which claimed that, as a result of the COVID-19 crisis, the EU is going to be eradicated. Also, other false articles claim that the SARS-CoV-2 was man-made in a laboratory from Wuhan, China ("EEAS special report update: short assessment of narratives and disinformation around the COVID-19 pandemic," 2020).

The panic related to an unprecedented situation like the pandemic with a lot of open questions regarding the future created the perfect environment for viral conspiracy theories and rumors (Ali, 2020). The online health information has been invaded by fake and misleading information, published intentionally or not. This made authorities in several countries especially the European Union member states to urge people to consult only reliable sources when researching COVID-19 ("Fighting disinformation," 2020). The mediated discussions around the novel coronavirus disease have influenced how people perceive the risk of being infected with the virus (Huynh, 2020).

Gordon Pennycook stated that "in the case of COVID-19, this misinformation comes in many forms - from conspiracy theories about the virus being created as a biological weapon in China to claims that coconut oil kills the virus" (Pennycook, McPhetres, Zhang, \& Rand, 2020, 2). This false information about the novel coronavirus that is spread in social media can determine people to appeal to miraculous remedies to cure the disease, to panic, or consider this pandemic as being untrue and harmless (Pennycook et al., 2020). Previous literature showed the dangers of fake news dissemination, the particular situation of the pandemic added to the risks: "the misinformation surrounding COVID-19 pandemic is especially damaging since any missteps can pose a serious public health risk by leading to exponential spread of the disease and accidental death due to self-medication" (Sharma et al., 2020, 1).

National and international organizations took measures to fight not only the spreading of the disease but also that of fake news. Thus, the World Health Organization, one of the leading international actors launched an online platform dedicated to debunking myths about COVID-19 (WHO, 2020). Furthermore, relevant online platforms took also some important steps in fighting disinformation and misinformation regarding COVID-19 ("EEAS special report update: short assessment of narratives and disinformation around the COVID-19 pandemic," 2020). Facebook stated in their policy regarding misinformation that they would eliminate from their platform "claims that are designed to discourage treatment or taking appropriate precautions" ("EEAS special report update: short assessment of narratives and disinformation around the COVID-19 pandemic," 2020). The social media platform also introduced a COVID-19 Information Center, so that Facebook users can access reliable information about the pandemic (Nielsen et al., 2020). 
Google introduced in Google Search "an SOS Alert, new knowledge panels, and an information and resources center for the virus" (Nielsen et al., 2020, 11).

The European Commission created an online platform - entitled Combating disinformation - where the most spread fake news about COVID-19 is being debunked. In this regard, on this platform, there is stated the fact that there is no connection between coronavirus and $5 \mathrm{G}$ networks, that no one is using the coronavirus crisis to impose mass vaccination, and that UE is supporting its member states and it does not fall apart as the result of the crisis ("Fighting disinformation," 2020). Also, to fight COVID-related disinformation, the European Parliament published on their website an article entitled Disinformation: how to recognize and tackle Covid-19 myths, which claimed that alongside the launch of the Combating disinformation platform, EU politicians and medical experts are regularly hosting video conferences to address the COVID-related fake news issue ("Disinformation: how to recognize and tackle Covid-19 myths," 2020).

In this context, our study aimed to analyze several COVID-19 related fake news disseminated in Romania via social media platforms that were identified as fake by the Romanian traditional media outlets. We are aware of the challenges of our research related to find a relevant sample and to choose the appropriate criteria to define fake news. We want to underline the exploratory nature of our research.

\section{Theoretical framework}

\section{Fake news}

The fake news phenomenon is not a new one. The production and the dissemination of the fake news trough out contemporary technology made it very relevant for the nowadays information environments. The term fake news gained public attention as a result of the 2016 US presidential elections (Zhang \& Ghorbani, 2019), the phenomena being also mentioned in the context of the Brexit campaign (Bârgăoanu, 2018).

Previous literature provided some definitions for the fake news term. For example, the Oxford Institute for the Study of Computational Propaganda defines fake news as "misleading, deceptive or incorrect information, purporting to be real news about politics, economics or culture" (Harsin, 2018, 101). Furthermore, in the Cambridge dictionary fake news is depicted as "false stories that appear to be news, spread on the internet or using other media, usually created to influence political views or as a joke" (Harsin, 2018, 100). Rochlin states that fake news implies intentionally publishing a false story on a website that mimics one of a trusted media outlet and distributing it in social media (Rochilin, 2017). Also, Lazer et al. claim that online disinformation refers to intentionally spreading false information to deceive readers. Fake news tackles refer to fabricated information that resembles in the form with trustful news articles, but not in content or intent (Lazer et al., 
2018, 1094). Fake news is "news articles that are intentionally and verifiably false, and could mislead readers" (Allcott \& Gentzkow, 2017, 213)

According to some authors there are seven types of misinformation and disinformation: satire or parody, misleading content, imposter content, fabricated content, false connection, false context, and manipulated content (Wardle \& Derakhshan, 2017, 17). Satire or parody refers to information that is not intended to cause harm, misleading content refers to the "misleading use of information to frame an issue or individual" (Wardle \& Derakhshan, 2017, 17), imposter content tackles the imitation of credible sources, fabricated content refers to invented content meant to cause harm to an entity, false connection deals with sensational headlines that do not support the content of the articles, false context refers to spreading trustful information while manipulating the context and manipulated content refers to the manipulation of credible information to deceive readers (Wardle \& Derakhshan, 2017, 17).

\section{Health-related fake news and COVID-19}

In the past years, technology evolved a lot, so that nowadays anyone can access any type of information on the Internet, especially medical information. This has a positive and a negative side. Anyone can access this type of information, but not all individuals have the ability to process and interpret medical information (Bolton $\&$ Yaxley, 2017, 8). Some individuals post and access medical information on social media platforms, but not all individuals have the required e-health literacy (Park, Bowling, Shaw, Li, \& Chen, 2019). One of the negative aspects observed was that many social media users prefer to seek medical advice on the internet, rather than consulting a medical doctor (Addawood, Balakumar, \& Diesner, 2019). They even prefer to take health-related decisions based on false information they read on the internet (Addawood et al., 2019). On this note, people who are diagnosed with a specific medical affection prefer to search online for miraculous treatments and remedies, thus harming their health (Bolton \& Yaxley, 2017). Online misinformation and disinformation are spread across virtual communities of like-minded individuals (Tucker et al., 2018). This can be the case of Facebook groups, where people who have the same interests share information. Even before the novel coronavirus pandemic, health-related fake news was a highly spread phenomenon that needed to get much more in the focus of communication research.

Because the COVID-19 pandemic is still ongoing, researchers that approached the issue of the novel coronavirus-related fake news are under development. However, Brennen et al. analyzed 225 false articles collected by First Draft News and also the engagement of these pieces of misinformation (Brennen, Simon, Howard, $\&$ Nielsen, 2020). The first conclusion that they reach is the fact that "the number of English-language fact-checks rose more than $900 \%$ from January to March" 
(Brennen et al., 2020, 1). They also concluded that most of the analyzed articles were partially true, having misleading or spun information, while a relatively low number of articles (38\%) were completely fabricated. Regarding the source of the misinformation articles, the majority of COVID-related misinformation from social networks originated from ordinary social media users, while $20 \%$ originated from public figures like politicians or influencers fact that determines the authors to state that influential public people can be agents that favor the spread COVID-19related misinformation (Brennen et al., 2020, 8). Also, with regards to the claims from these false articles, most of them tackled the authorities' actions taken in the coronavirus crisis: "much misinformation directly or indirectly questions the actions, competence, or legitimacy of public authorities (including governments, health authorities, and international organizations)" (Brennen et al., 2020, 8).

\section{eHealth literacy model}

When it comes to individuals' ability to interpret medical information they find on the Internet, the health literacy concept needs to be considered. Health literacy refers to "the degree to which individuals can obtain, process and understand basic health information and services needed to make appropriate health decisions" (Health Literacy: A Prescription to End Confusion, 2004; cited in Keselman, Smith, Murcko, \& Kaufman, 2019, 2), while, in the context of the digital society, eHealth literacy tackles the people's ability to seek and evaluate online health information (Keselman et al., 2019, 2). People with lower eHealth literacy levels will have difficulties in finding trustful information on the Internet, and they will have problems in understanding, for example, statistical or biological data they find on the internet.

Norman and Skinner introduced the eHealth literacy model having six types of literacy: computer literacy, information literacy, media literacy, conventional literacy and numeracy, scientific literacy, and health literacy (Norman \& Skinner, 2006; Keselman et al., 2019). Each dimension refers to a certain type of ability. Computer literacy refers to the ability to use a computer, information literacy refers to locate and evaluate information, media literacy tackles the capacity to think critically with regards to media content, conventional literacy and numeracy refer to the ability to read and interpret statistical data and graphics, scientific literacy tackles the ability to find and understand scientific information and research findings, while health literacy refers to finding, understanding and using health information (Norman \& Skinner, 2006, 5-6).

Keselman et al. (2019) developed a study entitled Evaluating the quality of Health Information in a Changing Digital Ecosystem that provides the instruments to analyze health information. Source credibility theory and fake news typologies (Wardle, 2017) contributed to the theoretical framework of our study. According 
to the source credibility theory, a source is considered credible if it has three characteristics: expertise, trustworthiness, and goodwill (Jennings \& Russell, 2019). An individual who considers a source to be credible is more likely to adopt and believe the information from that source.

The research question we focused on was: what are the informational characteristics of a COVID-19-related fake news article that were disseminated on the Internet and were identified as such by traditional media outlets?

\section{Methodology}

\section{Research design}

In order to answer the research question, a content analysis was conducted on a sample of $N=22$ COVID-19 related fake news speeded on the Internet. The sample consists of fake news that identified as such by the Romanian traditional media outlets in the time frame March the $13^{\text {th }}$ - May the $1^{\text {st }} 2020$. During this time first COVID-19 cases were diagnosed in Romania and protective measures within the state of emergency were implemented. Twenty COVID-19 related fake news articles and 2 fake Facebook posts regarding novel coronavirus were analyzed. Media outlets that are considered being credible by the Romanian public, Adevarul, PROTV, Digi24, and Hotnews published articles concerning the fake news that circulated in Romania during this time. A search was performed on these media outlets' websites looking for the two concepts: fake news and COVID-19. The results consist of 22 links with COVID-19 related fake news: 20 from the online press and two Facebook posts. This fake news was published on websites such cuvantul-ortodox.ro, tratamenteanticancer. wordpress.ro, puterea.ro, dir.org.ro, contramundum.ro, activenews.ro, or gandul.ro. All links with the 20 COVID-19-related fake news articles are illustrated in Appendix 2, while the 2 Facebook posts that were included in the sample for the analysis are illustrated in Appendix 3 and 4.

The coding scheme had 11 categories and 38 subcategories. The categories were Resource type, Characterization (Wardle, 2017), Source of the article, Validity of the content, Objectivity, Emotional appeal, Treatment or prevention methods, Promises and certainty, Criticism of establishment, Vocabulary, and Use of science in argumentation. Several examples of subcategories are: It is clear who is responsible for the content of the article? What are the author's academic or professional credentials? Does the news article make a claim of having a solution (approach or product) that is (a) quick, (b) painless or noninvasive, or implemented via a simple procedure or with simple ingredients, (c) relatively inexpensive? Is there a promise of complete recovery form COVID-19? (Keselman et al., 2019, 5). The entire coding scheme can be seen in Appendix 1. 


\section{Results}

Regarding the resource type of the 22 COVID-19-related fake news articles, 16 were online press content, and two were digitized content - news articles that were published both in traditional media and online media. Four were fake news articles from web 2.0 content: two Facebook posts and two blog posts from the wordpress. com platform.

The characterization (Wardle, 2017) for the types of mis- and disinformation was used in this context. Regarding the 22 COVID-related fake news articles that were analyzed, seven were characterized by misleading content, 13 were characterized by manipulated content, one was characterized by false context, and one was characterized by fabricated content. For example, one of the fake news articles claimed that a German virologist stated that the coronavirus is not as dangerous as the seasonal flu and that the lockdown measures taken by the governments are absurd. The specialist militated for the isolation of the older people only, letting the young ones to get infected (stirileprotv.ro, 2020).

Concerning the source of the article, 12 COVID-19-related fake news articles had no author mentioned, while ten had the author mentioned on the web page on which the article was published. From the 12 articles that had no author mentioned, the websites on which the articles were published were not credible sources. These articles were published o websites like ortodoxia.ro, cronicaromana.net, or oficialmedia.ro.

Ten of the articles had the author mentioned, but they were all journalists, except for one article in which the author was illustrated as Author-Off-Guardian. Form these ten articles that had the authors mentioned, one fake news article was published on a credible website of a trusted media outlet from Romania (PROTV), two were Facebook posts and their source was not credible, one was a blog post with a not credible source, and six were published on not credible websites like puterea.ro, dir.org.ro, or contramundum.ro. For all ten fake news articles that had the author mentioned, there was no indication of the author's qualifications, academic or professional credentials.

Phrases such as a study showed that were made without references or other pointers to the actual studies are indicators for the issue regarding the validity of the content (Keselman et al., 2019). For example, in a fake news article, there was a statement according to which "studies show that no antibiotics or other medicines, but the plain Vitamin C has a beneficial role in treating coronavirus" ("Shocking announcement: Vitamin C could kill the coronavirus!” 2020) but the actual study which claimed this was not cited.

Fifteen fake news articles had content that needed to be cited but it was not. For example, in an article, it was stated that "Dr. Yanis Rousel et al. - a team of researchers from the Marseille Institute of Infectious Diseases - conducted a peerreviewed study regarding the coronavirus mortality rate" (Nicolae, 2020), but the 
actual name of the study, its results or the journal which published the study were not mentioned. 12 articles included sources that may seem reliable, like doctors or virologists, so that their mention would give credibility to some specific statements.

Fifteen COVID-19-related fake news articles were published on web pages form dot.ro domain, tree was published on web pages from dot.com domain, one was published on a webpage from dot.net domain, and one was published on a webpage from dot.md domain. None of the articles were selling products and their content did not appear to be biased. Tree articles encouraged a certain action: one encouraged the isolation of old people instead of young ones, and the other two fake news articles encouraged the use of Vitamin $\mathrm{C}$ for treating the coronavirus.

None of the COVID-19-related-fake news articles contained disturbing photos or images, and only a single fake news article contained a testimonial from a doctor. The doctor claimed that Vitamin $\mathrm{C}$ is having miraculous effects if involved in the treatment of coronavirus patients. The emotional appeal dimension was not much represented.

Four fake news articles and one Facebook post brought up the issue regarding the COVID-19's treatment and the prevention measures against the virus. The Facebook post illustrated the story of a doctor from Botoșani who discovered the vaccine for COVID-19, but the content of the post was completely fabricated. The doctor wasn't a real medical doctor; it was an actor playing in adults' movies with no connection at all with the research in the field of anti-COVID-19 vaccination. The post emphasized the use of vaccines as a prevention method against coronavirus, but its content was entirely fabricated. Another fake news article proposed some prevention measures against COVID-19, namely the isolation of old people only, letting the young ones to get infected with the virus and gain immunity.

On the other hand, three fake news articles mentioned some treatment methods for coronavirus. One militated for the use of chloroquine and hydroxy-chloroquine, while the other two fake news articles suggested using Vitamin C for treating COVID-19 patients.

The specific promises made in every COVID-19 fake news article varied. In this regard, one fake news article promised a complete recovery from coronavirus, using chloroquine and hydroxy-chloroquine. Also, two fake news articles claimed that Vitamin $C$ is a quick, painless, and relatively inexpensive treatment for coronavirus. A promise for complete recovery was not mentioned in these 2 articles. However, in the article from cronicaromana.net it was stated that "in the case of four patients with severe pneumonia caused by the novel coronavirus, the increased doses of vitamin C had incredible effects" ("Shocking announcement: Vitamin C could kill the coronavirus!" 2020)

Eighteen COVID-19-related fake news articles included critical remarks about the government agencies, all of them implying that there is a conspiracy or purposeful misleading on the part of the government agencies or health officials. 
For example, in the fake news article from stirileprotv.ro there was a statement regarding a conspiracy in the part of a health institution: "The Robert Koch Institute pushes things too far. The disease is not as bad as the seasonal flu. The virus does not represent a cause for a severe illness" (stirileprotv.ro, 2020). Some articles claimed that there is no coronavirus and that the government keeps people locked down so that they can install 5G networks. Also, in another two fake news articles, it was stated that the government measures against the coronavirus are absurd and very dangerous: "the lives and the ways of lives of our citizens are exposed to risk to avoid an inexistent danger" ("Expert microbiologist Dr. Sucharit Bhakdi "shocked" Chancellery Merkel by blowing up the measures imposed in Germany: "They will do huge damage, they will not do any good!"," 2020).

All 22 COVID-19-related fake news articles were written using a simple, colloquial language so that every reader can understand the main ideas from the articles.

There were no biological mechanisms of diseases or treatments mentioned. One fake news article contained false claims - the one with the actor who invented the development of an anti-COVID-19. Five fake news articles contained exaggerated claims, like "the lives and the ways of lives of our citizens are exposed to risk to avoid an inexistent danger" ("Expert microbiologist Dr. Sucharit Bhakdi "shocked" Chancellery Merkel by blowing up the measures imposed in Germany: "They will do huge damage, they will not do any good!"," 2020). Sixteen articles included unverifiable statements. For example, in the article from medikatv.ro a doctor claimed that "Patients that received Vitamin C had a significant better evolution than those who did not receive Vitamin C. It helps a lot, but it is not promoted because it is not a modern drug" ("New York hospitals are treating COVID-19 patients with high dozes of Vitamin C," 2020). Another example in this regard is the statement from the fake news article published on cronicaromana.net: "studies show that not antibiotics, but the plain Vitamin C has a beneficial role in treating the coronavirus" ("Shocking announcement: Vitamin C could kill the coronavirus!” 2020).

\section{Discussion}

This study emphasizes the challenges for social media users when searching for health information on the Internet. As stated in the literature, anyone can access health information on the Internet, but not all individuals have the ability to process and interpret medical information (Bolton \& Yaxley, 2017). When it comes to seeking health information on the internet, both scientific literacy and media literacy, alongside health literacy, are extremely important. People need to have the capacity to identify the most trustworthy media sources and read information only from them. Also, individuals need to have the ability to understand properly scientific information, when they find it in a news article regarding a certain health 
topic. Furthermore, when searching for health information online, people need to be educated towards reading information that comes from authorities that are credible and accredited for spreading health information. Sources like the World Health Organization or the Centers for Disease Control and Prevention are most reliable when it comes to health and medical information.

Most often, people that have a medical condition prefer to search online for miraculous treatments and remedies, thus harming their health (Bolton \& Yaxley, 2017).

The results from the analysis showed that the media also published articled about using Vitamin $\mathrm{C}$ for treating the coronavirus, although, again, there is not enough evidence that the use of this substance is beneficial for COVID-19 patients. Moreover, in the analyzed sample there was also a Facebook post that claimed that a vaccine has been found for coronavirus. This type of news article gives people false hopes because in many cases finding an efficient vaccine for a specific disease can take months or even years. Also, the mass media dissemination of news articles claiming that there is a conspiracy on the part of the government can have negative effects on people. These types of news articles spread fear into the population and can determine the individuals to revolt against the government measures.

\section{Conclusion}

This pilot study aimed to analyze COVID-19 related fake news from Romania that were identified as fake by the Romanian mass-media and the informational characteristics of a COVID-19-related fake news article. As shown in the results section, several informational characteristics were identified. First of all, the results emphasize the fact that the fake news articles varied concerning the author's mention. Most of the articles were characterized by manipulated content. Also, most of the articles included content that needed to be cited, but it was not. Several articles mentioned treatment for the disease, and some mentioned the vaccine as a prevention measure against COVID-19. The articles were written in a colloquial language, and the majority of the fake news articled included criticism towards the government and their measures against the pandemic. Furthermore, most of the articles contained unverifiable claims, while some of them included false or exaggerated statements.

The research has some limitations, like the number of analyzed COVID-19-related fake news. The sample was designed this way because an instrument for collecting coronavirus-related fake news articles from Facebook could not be accessed. Only the Romanian media identified limited fake news articles. Another limit of the study is the fact that a single coder conducted the analysis, so the results are subjective. Concerning future research on this topic, it would be useful to conduct a study on a larger number of COVID-19-related fake news articles. Also, it would be interesting 
to research to find out how the media behavior of Romanians changed during the coronavirus pandemic.

\section{References}

1. Addawood, A., Balakumar, P., \& Diesner, J. (2019). Categorization and Comparison of Influential Twitter Users and Sources Referenced in Tweets for Two Health-Related Topics. Paper presented at the iConference.

2. Ali, I. (2020). The COVID-19 Pandemic: Making Sense of Rumor and Fear. Medical Anthropology. Cross-Cultural Studies in Health and Illness, 1-4. doi: 10.1080/0145974 0.2020 .1745481 .

3. Allcott, H., \& Gentzkow, M. (2017). Social media and fake news in the 2016 election. The fournal of Economic Perspectives, 31(2), 211-236.

4. Bârgăoanu, A. (2018). \#Fakenews: noua cursă a înarmării. București: Evrika Publishing.

5. Bolton, D. M., \& Yaxley, J. (2017). Fake news and clickbait - natural enemies of evidencebased medicine. BfU International, 119(5), 8-9.

6. Brennen, J. S., Simon, F. M., Howard, P. N., \& Nielsen, R. K. (2020). Types, Sources, and Claims of COVID-19 Misinformation. https://reutersinstitute.politics.ox.ac.uk/typessources-and-claims-covid-19-misinformation.

7. Disinformation: how to recognise and tackle Covid-19 myths. (2020). Retrieved from https://www.europarl.europa.eu/news/en/headlines/society/20200326STO75917/ disinformation-how-to-recognise-and-tackle-covid-19-myths.

8. EEAS special report update: short assessment of narratives and disinformation around the COVID-19 pandemic. (2020). Retrieved from https://euvsdisinfo.eu/eeas-special-reportupdate-short-assessment-of-narratives-and-disinformation-around-the-covid-19-pan demic/?fbclid=IwAR311gFVXqcOwSDyNHcTDLY14I9Lp_v-g1yS13EQIUTVt4Ud5Q-GAbPKuE.

9. Expert microbiologist Dr Sucharit Bhakdi "shocked" Chancellery Merkel by blowing up the measures imposed in Germany: "They will do huge damage, they will not do any good!”. (2020). Retrieved from http://www.e-politic.ro/stiri/expertul-microbiologdr-sucharit-bhakdi-a-ucarit-cancelaria-merkel-aruncand-in-aer-masurile-impuse-ingermania-vor-face-pagube-uria-e-nu-vor-face-niciun-bine-1365185.

10. Fighting disinformation. (2020). Retrieved from https://ec.europa.eu/info/live-worktravel-eu/health/coronavirus-response/fighting-disinformation_ro.

11. Harsin, J. (2018). A critical guide to fake news: from comedy to tragedy. Pouvoirs, 1(164), 99-119.

12. Health Literacy: A Prescription to End Confusion. (2004). Retrieved from Washington, DC.

13. Hickok, K. (2020). Husband and wife poison themselves trying to self-medicate with chloroquine. Retrieved from https://www.livescience.com/coronavirus-chloroquine-selfmedication-kills-man.html.

14. Huynh, T. L. D. (2020). The COVID-19 risk perception: A survey on socioeconomics and media attention. Economics Bulletin, 40(1), 758-764. 
15. Jennings, F. J., \& Russell, F. M. (2019). Civility, credibility, and health information: The impact of uncivil comments and source credibility on attitudes about vaccines. Public Understanding of Science, 28(4), 417-432. doi: 10.1177/0963662519837901.

16. Keselman, A., Smith, C. A., Murcko, A. C., \& Kaufman, D. R. (2019). Evaluating the Quality of Health Information in a Changing Digital Ecosystem. Fournal of Medical Internet Research, 21(2), e11129. doi: 10.2196/11129.

17. Kouzy, R., Jaoude, J. A., Kraitem, A., Alam, M. B. E., Karam, B., Adib, E., ... Baddour, K. (2020). Coronavirus Goes Viral: Quantifying the COVID-19 Misinformation Epidemic on Twitter. Cureus, 12(3), e7255. doi:10.7759/cureus.7255.

18. Kwok, K. O., Li, K.-K., Chan, H. H. H., Yi, Y. Y., Tang, A., Wei, W. I., \& Wong, S. Y. S. (2020). Community responses during the early phase of the COVID-19 epidemic in Hong Kong: risk perception, information exposure and preventive measures. medRxiv.

19. Lazer, D. M. J., Baum, M. A., Benkler, Y., Berinsky, A. J., Greenhill, K. M., Menczer, F., ... Zittrain, J. L. (2018). The science of fake news. Science, 359(6380), 1094-1096.

20. Nicolae, A. (2020). 12 well-known experts speak out against hysteria in Covid 19. Dr. Sucharit Bkakdi (Germany): Government measures against Covid19 are grotesque, absurd and very dangerous. Retrieved from https://www.activenews.ro/stiri-sanatate/12experti-de-nivel-mondial-se-exprima-impotriva-isteriei-Covid-19.-Dr.-Sucharit-BkakdiGermania-Masurile-guvernului-impotriva-Covid19-sunt-grotesti-absurde-si-foartepericuloase-160746.

21. Nielsen, R. K., Fletcher, R., Newman, N., Brennen, J. S., \& Howard, P. N. (2020). Navigating the 'Infodemic': How People in Six Countries Access and Rate News and Information about Coronavirus. Retrieved from Reuters Institute for the Study of Journalism.

22. Norman, C. D., \& Skinner, H. A. (2006). eHealth Literacy: Essential Skills for Consumer Health in a Networked World. Journal of Medical Internet Research, 8(3), e9.

23. Nwr York hospitals are treating Covid 19 patients with high dozes of Vitamin C. (2020). Retrieved from https://medikatv.ro/spitalele-mari-din-new-york-trateaza-pacientii-cov id-19-cu-doze-mari-de-vitamina-c/.

24. Park, A., Bowling, J., Shaw, G. J., Li, C., \& Chen, S. (2019). Adopting Social Media for Improving Health: Opportunities and Challenges. N C Med J., 80(4), 240-243.

25. Pennycook, G., McPhetres, J., Zhang, Y., \& Rand, D. G. (2020). Fighting COVID-19 misinformation on social media: Experimental evidence for a scalable accuracy nudge intervention.

26. Rochilin, N. (2017). Fake news: Belief in post-truth. Library Hi Tech, 35(3), 386-392.

27. Sharma, K., Seo, S., Meng, C., Rambhatla, S., Dua, A., \& Liu, Y. (2020). Coronavirus on social media: analysing misinformation in twitter conversations. PsyArXiv Preprints.

28. Shimizu, K. (2020). 2019-nCoV, fake news, and racism. The Lancet, 395. doi: https://doi. org/10.1016/S0140-6736(20)30358-5.

29. Shocking announcement: Vitamin C could kill the coronavirus! (2020). Retrieved from https://cronicaromana.net/2020/03/10/anunt-soc-vitamina-c-ucide-coronavirusul/.

30. stirileprotv.ro. (2020). The controversial opinion of a German virologist: Protect only the elderly, young people should be allowed to infect each other. Retrieved from https:// 
stirileprotv.ro/stiri/international/opinia-controversata-a-unui-virusolog-germanprotejati-doar-batranii-tinerii-trebuie-lasati-sa-se-infecteze-unii-pe-altii.html.

31. Sun, K., Chen, J., \& Viboud, C. c. (2020). Early epidemiological analysis of the coronavirus disease 2019 outbreak based on crowdsourced data: a population- level observational study. Lancet Digital Health, 1-8. doi: https://doi.org/10.1016/S2589-7500(20)30026-1.

32. Tucker, J. A., Guess, A., Barbera, P., Vaccari, C., Siegel, A., Sanovich, S., ... Nyhan, B. (2018). Social Media, Political Polarization, and Political Disinformation: A review of the Scientific Literature. http://dx.doi.org/10.2139/ssrn.3144139.

33. Wardle, C. (2017). Fake news. It's complicated. Retrieved from https://firstdraftnews.org/ latest/fake-news-complicated/.

34. Wardle, C., \& Derakhshan, H. (2017). Information Disorder: Toward an interdisciplinary framework for research and policymaking. Retrieved from https://firstdraftnews.org/ research/.

35. WHO. (2020). Coronavirus disease (COVID-19) advice for the public: Myth busters. Retrieved from https://www.who.int/emergencies/diseases/novel-coronavirus-2019/adv ice-for-public/myth-busters.

36. WHY DID SO MANY CORONAVIRUS PATIENTS DIED IN ITALY? / CRITICAL OPINIONS OF MEDICAL EXPERTS ON EXTREME MEASURES AGAINST COVID-19. "All these measures lead to SELF-DESTRUCTION and collective suicide". (2020). Retrieved from http://www.cuvantul-ortodox.ro/recomandari/de-ce-au-murit-atat-demulti-pacienti-cu-coronavirus-in-italia-opinii-critice-ale-unor-experti-medicali-fata-demasurile-extreme-impotriva-covid-19-toate-aceste-masuri-conduc-la-autodistru/.

37. Zhang, X., \& Ghorbani, A. A. (2019). An overview of online fake news: Characterization, detection, and discussion. Information Processing and Management, 57(2). doi: 10.1016/j. ipm.2019.03.004. 


\section{Appendices}

\section{Appendices 1.}

Coding scheme (adapted Keselman et al., 2019, 5)

\begin{tabular}{|c|c|}
\hline Category & Subcategories \\
\hline Resource type & $\begin{array}{l}\text { - Digitized content (news articles simultaneously published in traditional mass media) } \\
\text { - Online press content } \\
\text { - Web } 2.0 \text { content (Blogs, support groups, online communities, social networking sites, } \\
\text { YouTube videos) }\end{array}$ \\
\hline $\begin{array}{l}\text { Characterization } \\
\text { (Wardle, 2017) }\end{array}$ & $\begin{array}{l}\text { satire or parody, misleading content, imposter content, fabricated content, false connec- } \\
\text { tion, false context and manipulated content }\end{array}$ \\
\hline $\begin{array}{l}\text { Source } \\
\text { of the article }\end{array}$ & $\begin{array}{l}\text { - It is clear who is responsible for the content of the article? } \\
\text { - What are the author's academic or professional credentials? } \\
\text { - Is there any indication of the author's qualifications for writing on a particular topic? } \\
\text { - Is there a credible source? }\end{array}$ \\
\hline $\begin{array}{l}\text { Validity } \\
\text { of the content }\end{array}$ & $\begin{array}{l}\text { - Is there content that needs to be cited, but is not? } \\
\text { - Are there sources for factual information clearly listed or cited so they can be verified in } \\
\text { another source? (if it is the case, are the authors of testimonials verifiable?) } \\
\text { - Is the information from sources known to be reliable? } \\
\text { - Do citations or references actually support the information illustrated in the news article? } \\
\text { - Are there endorsements by celebrity nonexperts? } \\
\text { - Is there mention of "secret recipe" (virtually unknown method) known only to the article's } \\
\text { authors or promoters? }\end{array}$ \\
\hline Objectivity & $\begin{array}{l}\text { - Does the content appear to contain any evidence of bias? } \\
\text { - Is the news article selling a product? } \\
\text { - Does the news article encourage a certain action? }\end{array}$ \\
\hline Emotional appeal & $\begin{array}{l}\text { - Does the news article contain emotional testimonials or personal anecdotes? } \\
\text { - Does the news article contain disturbing photos or images of health care professionals } \\
\text { or procedures? }\end{array}$ \\
\hline $\begin{array}{l}\text { Treatment or } \\
\text { prevention methods }\end{array}$ & $\begin{array}{l}\text {-What is the proposed treatment? } \\
\text { - What are the proposed prevention measures against COVID-19? }\end{array}$ \\
\hline $\begin{array}{l}\text { Promises } \\
\text { and certainty }\end{array}$ & $\begin{array}{l}\text { - Does the news article make a claim of having a solution (approach or product) that is (a) } \\
\text { quick, (b) painless or noninvasive or implemented via a simple procedure or with simple } \\
\text { ingredients, (c) relatively inexpensive? } \\
\text { - Is there a promise of complete recovery form COVID-19? }\end{array}$ \\
\hline $\begin{array}{l}\text { Criticism } \\
\text { of establishment }\end{array}$ & $\begin{array}{l}\text { - Is there implication or statement of conspiracy or purposeful misleading on the part } \\
\text { of: (a) pharmaceutical companies, (b) doctors or conventional health care providers, } \\
\text { (c) government agencies? } \\
\text { - Are there suggestions of media bias in covering relevant health issues? } \\
\text { - Are there implications or statements that the reader's or viewer's doctor is incompetent? } \\
\text { - Are there criticisms of biomedical research supporting the establishments' guidelines? } \\
\text { (eg. Methodology and research focus because of funding) }\end{array}$ \\
\hline Vocabulary & $\begin{array}{l}\text { - Does the page refer to cure or other words that are unlikely to be used in evidence-based } \\
\text { medicine literature? (eg. proven) } \\
\text { - Is the language very colloquial? }\end{array}$ \\
\hline
\end{tabular}


- Are biological mechanisms of diseases and treatments presented?

- Are there claims that the coder perceives as: Exaggerated? False? Unverifiable? Mention-

Use of science ing controversial or not quite scientific concepts? Otherwise problematic?

in argumentation

- Is there a contrast between claims about the complexity or uncertainty of the condition or treatment and the simplicity and certainty of the proposed solution? (statements that are too good to be true).

\section{Appendices 2.}

\section{Links with COVID-19 related fake news articles}

1. https://www.national.ro/news/tratamentul-pentru-covid-exista-medicii-romani-nu-auvoie-sa-l-prescrie-682017.html/

2. https://stirileprotv.ro/stiri/international/opinia-controversata-a-unui-virusologgerman-protejati-doar-batranii-tinerii-trebuie-lasati-sa-se-infecteze-unii-pe-altii.html

3. https://medikatv.ro/spitalele-mari-din-new-york-trateaza-pacientii-covid-19-cu-dozemari-de-vitamina-c/

4. https://cronicaromana.net/2020/03/10/anunt-soc-vitamina-c-ucide-coronavirusul/

5. https://ortodox.info.ro/2020/05/02/bill-gates-testeaza-in-kenya-si-malawi-un-carnet-devaccinare-injectat-sub-piele/

6. https://ortodox.info.ro/2020/04/30/document-guvernul-ar-fi-agravat-deliberat-frica-inrandul-populatiei-oamenii-ar-trebui-sa-se-teama-ca-vor-fi-infectati-sau-ca-parintii-sibunicii-lor-vor-muri/

7. https://ortodox.info.ro/2020/04/21/se-pregateste-omorarea-pensionarilor-in-lagare-deconcentrare-si-exterminare/

8. https://www.activenews.ro/stiri-sanatate/12-experti-de-nivel-mondial-se-exprimaimpotriva-isteriei-Covid-19.-Dr.-Sucharit-Bkakdi-Germania-Masurile-guvernuluiimpotriva-Covid19-sunt-grotesti-absurde-si-foarte-periculoase-160746

9. http://www.cuvantul-ortodox.ro/recomandari/de-ce-au-murit-atat-de-multi-pacienticu-coronavirus-in-italia-opinii-critice-ale-unor-experti-medicali-fata-de-masurileextreme-impotriva-covid-19-toate-aceste-masuri-conduc-la-autodistru/

10. https://tratamenteanticancer.wordpress.com/2020/03/28/12-doctori-experti-inclusivepidemiologi-despre-coronavirus/

11. https://www.puterea.ro/externe/guvernele-nu-pot-inchide-lumea-intreaga-pentru-tot deauna-192090.html

12. https://www.ziuanews.ro/stiri/expertul-microbiolog-dr-sucharit-bhakdi-a-uc-ritcancelaria-merkel-aruncand-in-aer-masurile-impuse-in-germania-vor-face-pagubeuria-e-nu-vor-face-niciun-bine-1429495

13. http://www.e-politic.ro/stiri/expertul-microbiolog-dr-sucharit-bhakdi-a-ucaritcancelaria-merkel-aruncand-in-aer-masurile-impuse-in-germania-vor-face-pagubeuria-e-nu-vor-face-niciun-bine-1365185

14. https://oficialmedia.com/medic-renumit-din-germania-masurile-guvernului-impotrivacovid19-sunt-grotesti-absurde-si-foarte-periculoase/ 
15. https://saccsiv.wordpress.com/2020/03/28/lumea-justitiei-ravagiile-covid-19-sunto-nalucire-exploziv-profesorul-de-microbiologie-moleculara-sucharit-bhakdi-dingermania-avertizeaza-995-din-cei-infectati-nu-sunt-bolnavi-cu-adeva/

16. https://www.dir.org.ro/dr-sucharit-bhakdi-germania-masurile-guvernului-impotrivacovid-19-sunt-grotesti-absurde-si-foarte-periculoase-toate-aceste-masuri-conduc-laautodistrugere-si-sinucidere-colectiva-pe-baza-a-nimi/

17. http://ortodoxia.ro/article/12-experti-de-nivel-mondial-se-exprima-impotriva-isterieicovid-19-dr-sucharit-bkakdi-germania-masurile-guvernului-impotriva-covid19-sunt-grotesti-absurde-si-foarte-periculoase

18. http://contramundum.ro/2020/03/27/expertii-contra-isteriei-covid/

19. https://ro.sputnik.md/International/20200331/29714405/Declaratia-fulminanta-care-dapeste-cap-teoria-Coronavirus-si-contesta-masurile-radicale.html

20. https://www.gandul.ro/stiri/sportiv-celebru-despre-pandemie-nu-cred-ca-vine-dinchina-este-o-minciuna-de-vina-sunt-retelele-5g-19418206?fbclid=IwAR1Lr_5hK5o79Jkr oHkkD3C2t1hR0Ut9l2Fm7JG5NGP5dWKgNROq-2lqoeo

\section{Appendices 3}

Facebook post - doctor who discovered vaccine

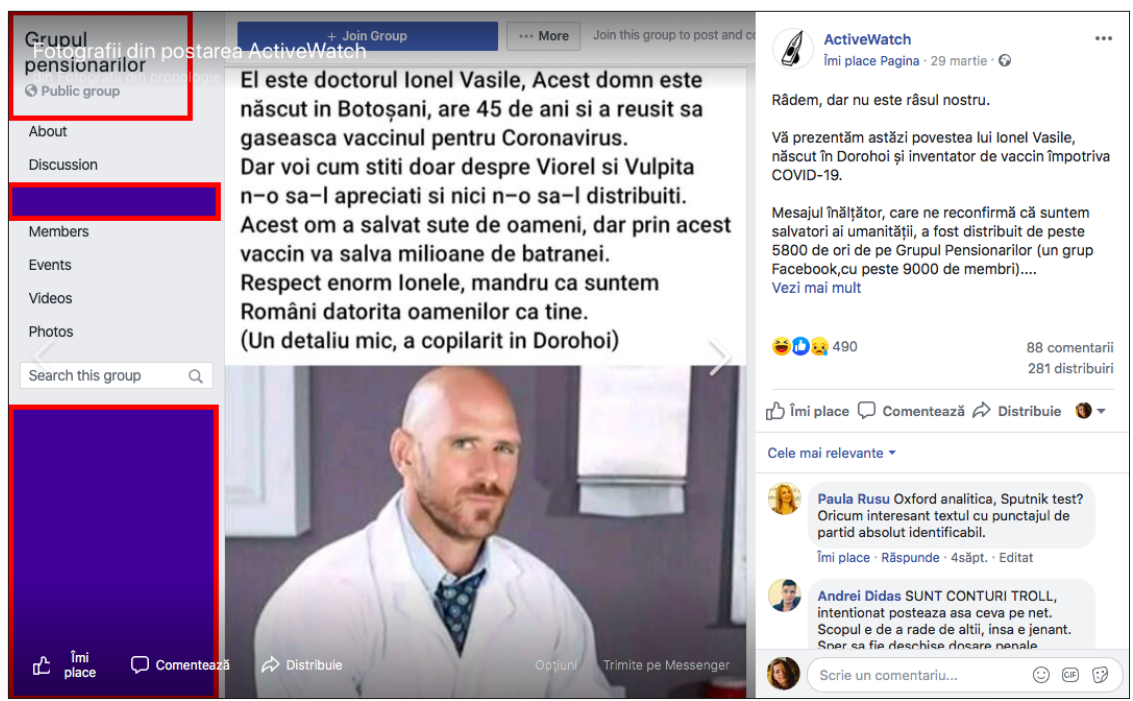

\section{Appendices 4.}

Facebook post - professor arrested for selling the coronavirus to China: https:// www.ziaruldeiasi.ro/stiri/stirea-falsa-care-a-facut-inconjurul-lumii-om-destiinta-arestat-pentru-ca-a-vandut-chinei-virusul-covid-19--249056.html 